Review

\title{
Natural Pectin Polysaccharides as Edible Coatings
}

\author{
Arantzazu Valdés, Nuria Burgos, Alfonso Jiménez and María Carmen Garrigós * \\ Department of Analytical Chemistry, Nutrition \& Food Sciences, University of Alicante, Campus San \\ Vicente, 03690 San Vicente del Raspeig (Alicante), Spain; E-Mails: arancha.valdes@ua.es (A.V.); \\ nuria.burgos@ua.es (N.B.); alfjimenez@ua.es (A.J.)
}

* Author to whom correspondence should be addressed; E-Mail: mc.garrigos@ua.es; Tel.: +34-96-590-1242; Fax: +34-96-590-3697.

Academic Editor: Stefano Farris

Received: 30 September 2015 / Accepted: 11 November 2015 / Published: 16 November 2015

\begin{abstract}
The most fashionable trends in food packaging research are targeted towards improvements in food quality and safety by increasing the use of environmentally-friendly materials, ideally those able to be obtained from bio-based resources and presenting biodegradable characteristics. Edible films represent a key area of development in new multifunctional materials by their character and properties to effectively protect food with no waste production. The use of edible films should be considered as a clean and elegant solution to problems related with waste disposal in packaging materials. In particular, pectin has been reported as one of the main raw materials to obtain edible films by its natural abundance, low cost and renewable character. The latest innovations in food packaging by the use of pectin-based edible films are reviewed in this paper, with special focus on the use of pectin as base material for edible coatings. The structure, properties related to the intended use in food packaging and main applications of pectins are herein reported.
\end{abstract}

Keywords: pectin; edible films; biopolymer coatings; fruits; vegetables; agricultural wastes; revalorisation

\section{Introduction}

Food packaging systems have been traditionally considered as simple containers to transport food from the place where they have been produced to the retail outlet and then to the consumer with no 
alteration of the food nutritional and organoleptic characteristics. Nevertheless, these systems are often unable to increase the shelf-life of fresh food resulting in a problem to producers, retailers and consumers. Since the main function of packaging is preservation of food from external contamination, other important features such as retardation of deterioration, extension of shelf-life, protection from transport impacts and maintenance of the food quality should be taken into account. Packaging materials should protect food from environmental influences such as heat, moisture, oxygen, enzymes, loss of aromas and unpleasant odor components, as well as from the attack from micro and macro-organisms. Furthermore, the global market is becoming more demanding and is continuously in need of novel and stable products which, at the same time, could retain the natural properties of food. In summary, the demand for new packaging materials and food packaging functionalities is increasing.

Among materials currently used in food packaging, polymers have taken a major share because of their versatility and advantageous performance/cost ratio. However, the most important polymers used for food packaging are obtained from non-renewable resources and they are not biodegradable or compostable, representing a global environmental problem. These drawbacks in the use of common polymers in food packaging are becoming an important issue in the design of attractive systems for distribution, making consumers aware of the problems related to the waste disposal. Although the stability of food packaging materials during the food shelf-life is an advantage, it turns into a disadvantage when the package enters the post-use phase. In summary, the use of polymers obtained from non-renewable resources and non-biodegradable in food packaging applications represents an important environmental impact and waste generation issue. In fact, packaging waste accounted for 32.5 million tons or $17.7 \%$ of the total municipal solid waste (MSW) in 2013 in the USA [1] and 19.3 million tons or around 25\% in 2014 in Europe [2]. Currently, landfilling is the dominant method of packaging waste disposal, followed by recycling, incineration and composting. Even though recovery methods such as reuse, recycling and/or composting are encouraged as a way of reducing packaging waste disposal, there is still much work to do to substantially reduce the quantity of plastics present in MSW [3].

Some alternative packaging materials obtained from renewable resources, such as poly(lactic acid), PLA, poly(hydroxyalkanoates) (PHAs), starch or proteins, have been proposed as alternatives to non-biodegradable polymers in food packaging applications [4-7]. However, polysaccharides are gaining some space in their use as innovative packaging materials by their ubiquitous presence in Nature, as well as by their relative low cost compared to other biopolymers and the possibilities they offer to be used not only as polymer matrices but also in coatings. Polysaccharides are therefore strong environmentally-sound contenders in the food packaging market that fulfill all the environmental concerns (i.e., derived from renewable raw materials and biodegradable) while being even possible to be metabolized by human body together with food, making them able to be used in edible films.

Polysaccharides are the main component of biomass, being the most abundant renewable polymer resources available from Nature. Among them, pectin is one of the most significant since the pectin world market demand is increasing, reaching a total production capacity around 45-50 Mton per year while the demand was around 140-160 Mton per year in 2011, showing that the industry interest on this complex polysaccharide is rising day by day.

One of the most important features in the still incipient commercial application in food packaging of bio-based polymers is the use of some of these materials (e.g., PLA, PHAs) for rigid containers [8], but flexible morphologies are still dependent on the use of additives. In addition, commercial biopolymers 
show some limitations in terms of performance (thermal resistance, poor barrier and brittleness) as well as high costs. In fact, the present situation is such that the development of polysaccharides-based materials in fields where unique performance or raw material characteristics show an added technological value (for instance, sourced from renewable materials, biodegradability, water barrier, antimicrobial properties, aroma barrier) or marketing-wise (e.g., green or sustainability image) is both a challenge and an opportunity for the food packaging industries.

The term edible coatings in food applications correspond to thin layers of edible materials applied onto surfaces of highly perishable foodstuff, such as fresh-cut fruits and vegetables. The aim of this paper is the full review of the properties and possible applications of pectin in the manufacture of edible films for food packaging. The most recent scientific and technological developments in this field will be highlighted and our goal would be to permit the reader getting a complete survey of the increasing use of this biopolymer in food industries.

\section{Structure and Classification of Pectic Substances}

Pectin is a white, amorphous and colloidal carbohydrate of high molecular weight occurring in ripe fruits, especially in apples, currants, etc., and used in fruit jellies, pharmaceuticals and cosmetics for its thickening and emulsifying properties and ability to solidify to a gel. All these properties and applications have put pectin in the market of the biopolymers with great potential and possibilities for future developments. The structure of these polysaccharides is discussed in this section.

Pectic substances are present in the primary cell walls and middle lamellae of many plants and fruits, and they are frequently associated with cellulose, hemicellulose and lignin structures [9]. Their presence in the cell is important for some essential functions: (a) adhesion between cells; (b) mechanical strength of the cell wall; (c) ability to form stabilizing gels; and (d) they play a significant role in the growth of plant cells [10]. Pectin forms the most complex class of polysaccharides, mainly composed by high molecular weight heterogeneous groups of glycanogalacturonans and acidic structural polysaccharides with diverse structures. Pectin backbone consists of $(1 \rightarrow 4)$ - $\alpha$-D-galacturonic acid molecules linked to a small number of rhamnose residues in the main chain and arabinose, galactose and xylose in the side chains [11]. Several authors stated that pectin polysaccharides can be classified in three types (Figure 1) [12-14].

Homogalacturonan (HG) is a linear polymer formed by D-galacturonic acid and it can be classified into three different families depending on the acetylation or methylation reactions suffered during polymerization: (i) pectin with more than $75 \%$ of methylated carboxyl groups; (ii) pectinic acid with less than $75 \%$ of methylation; and, finally, (iii) pectic acid or polygalacturonic acid without methyl-esterified carboxyl groups [12]. Is the bold/italics necessary?

Rhamnogalacturonan I (RGI) is composed by the repeating disaccharide rhamnose-galacturonic acid groups acetylated and linked to side chains of neutral sugars, such as galactose, arabinose and xylose. Finally, rhamnogalacturonan II (RGII) is also formed by homogalacturonan chains, but with complex side groups attached to 12 different types of glycosyl residues, such as rare sugar species (2-O-methyl xylose, 2-O-methyl fucose, aceric acid, 2-keto-3-deoxy-D-lyxo heptulosaric acid, and 2-keto-3-deoxyD-manno octulosonic acid). RGI and RGII are called hairy regions in the pectin structure whereas HG is the smooth part of the molecule $[13,14]$. 


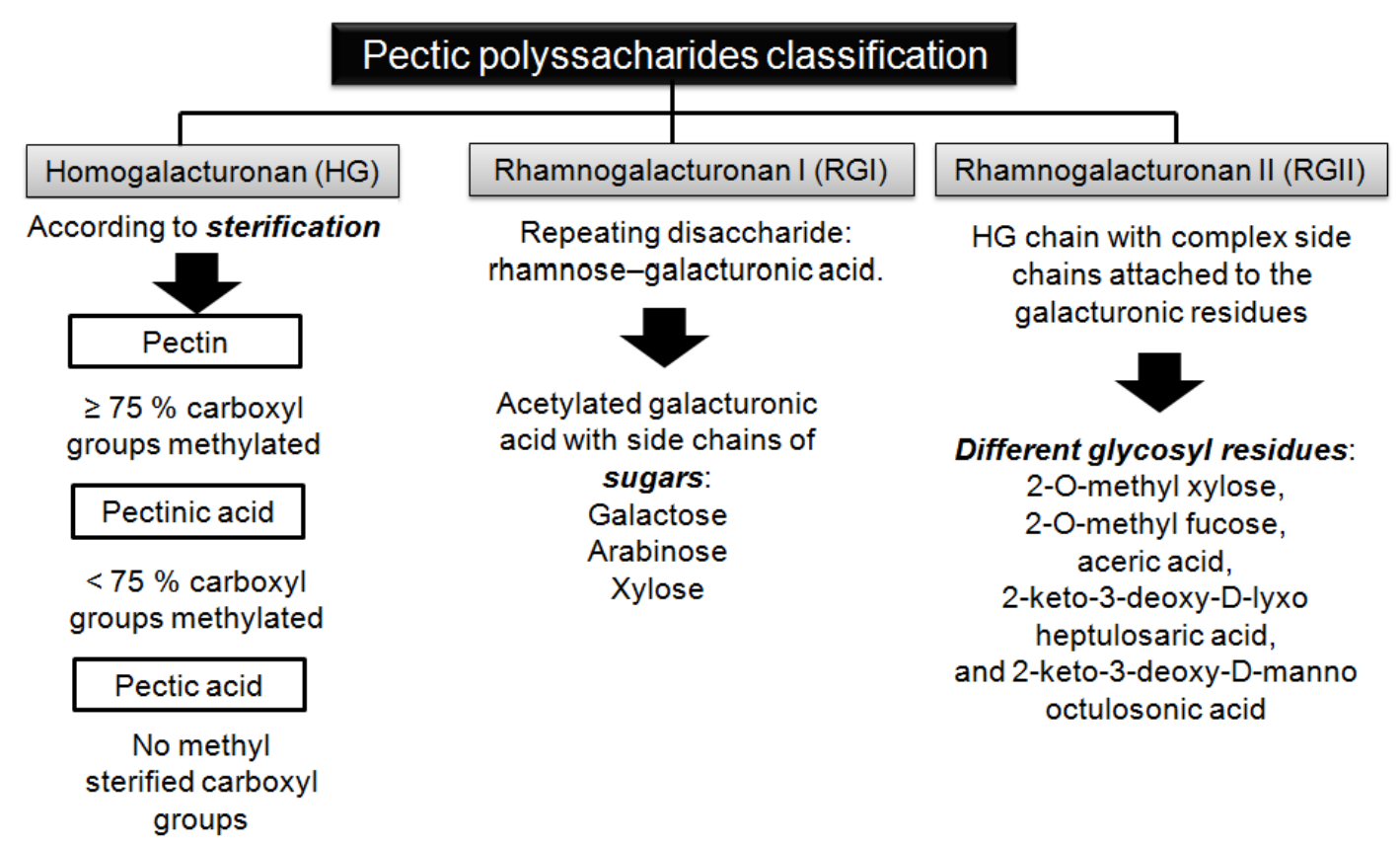

Figure 1. Classification of pectic polyssacharides based on D-galacturonic acid [12-14].

\section{Properties and Current Applications in Food Industry}

In general terms, pectins are used in food industry as stabilizers, thickening and gelling agents, crystallization inhibitors and encapsulating agents. But, in all cases, galacturonic residues should be previously modified by the addition of methyl groups to yield methoxides. This chemical modification is essential to improve pectins physical properties, which are dependent on their molecular masses and, primarily, on the degree of methyl-esterification (DM), calculated as moles of methanol per 100 moles of galacturonic acid [15]. In this context, two different DM degrees can be achieved resulting in different applications [10]:

- Pectins with high DM (HM pectins) containing 50\% or higher of galacturonic residues. They are used as gelling component in heat-resistant bakery jams, fruit preservatives and juices, confectionaries jellies, milky products, glazing cakes and soft drinks. HM pectins form gels by hydrophobic interactions under acidic conditions in aqueous media and high sugar content.

- Pectins with low DM (LM pectins) are obtained by de-esterification of HM pectins under controlled $\mathrm{pH}$, temperature and time. LM pectins show DM degrees between $20 \%$ and $30 \%$ [16]. They are used to prepare gels at low $\mathrm{pH}$ values in the presence of divalent calcium. Applications in food industry include jams and jellies with low-sugar content, dairy desserts, ice cream with fruit gels, thickening agents of syrups for fruit and vegetable canning and food coatings.

In this context, edible coatings obtained from pectin and derivatives (pectate and amidated pectin) have been recently proposed in food-related applications by their excellent barrier to oxygen, aroma preservation, barrier to oil and good mechanical properties, but they are not effective against moisture transfer through films by their hydrophilic nature [17]. They are currently used in fresh and minimally processed fruits and vegetables, such as avocado, apple, apricot, chestnuts, berries, guava, melon, papaya, peach, walnuts, carrot and tomato [17]. Depending on the product, three different coating methods can be used, as shown in Figure 2 [18]. 

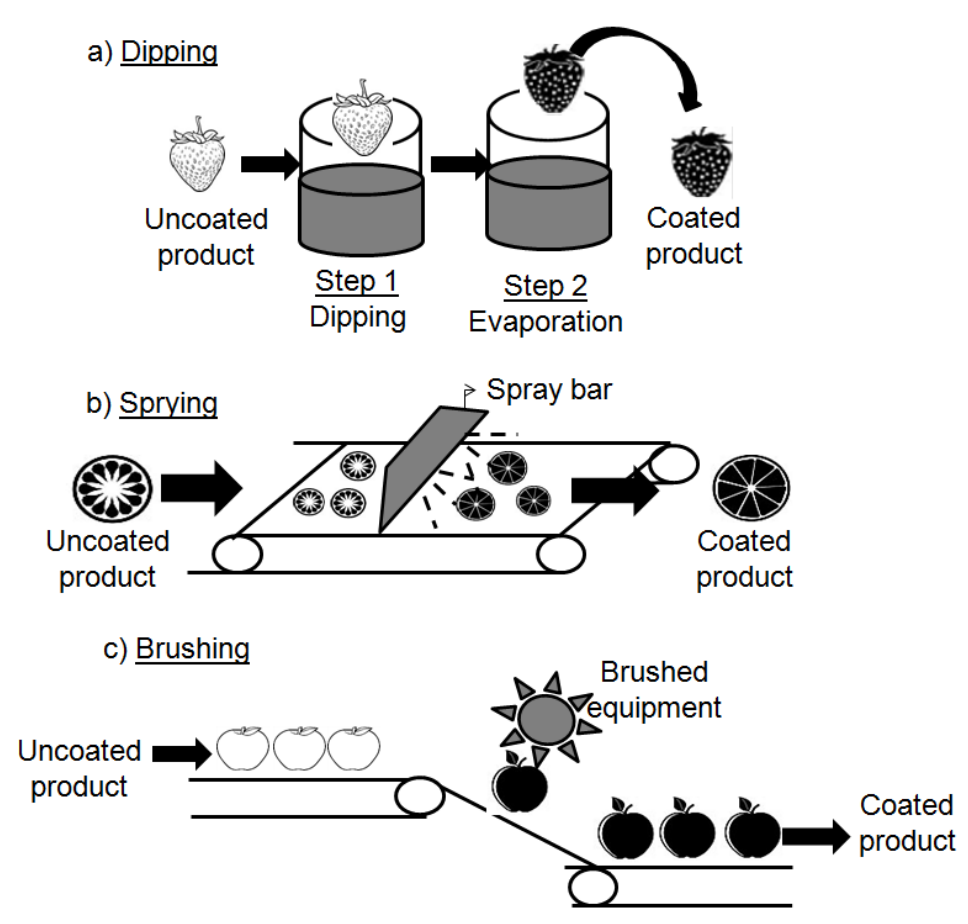

Figure 2. Main coating methods used in food industry. (Adapted from ref. [18]).

According to Dhanapal et al [18], dipping is the most common method to apply coatings to fruits and vegetables when the coating solution is highly viscous (Figure 2a). It is carried out by introducing the product for a time between 5 and $30 \mathrm{~s}$ in a coating solution under controlled conditions of density and surface tension.

However, when the coating solution is not highly viscous, spraying can be used (Figure 2b). The food product is introduced into the coating system and it is sprayed by controlling the final drop size of the spray solution, which depends on the thickness of the spray gun, nozzle temperature, air and liquid flow rates, humidity of incoming air and polymer solution, drying time and temperature [18]. The usual spraying instrument in this application can produce fine sprays, with drop-size distributions up to $20 \mu \mathrm{m}$. Finally, the brushing method is used in some products, such as fresh beans and strawberries, when the reduction of the moisture loss is an issue (Figure 2c). Thin coatings onto the surface of the product are obtained in all cases and they could act as semi-permeable membranes reducing gas transfer rates and creating new packaging materials to extend food shelf-life.

\section{Extraction Methods for Pectins: New Trends for the Revalorization of Agricultural Residues}

Pomace from apples, citric albedo, sugar beet pulp and sunflower rinds have been proposed as by-products from the agricultural and food industries to obtain pectic substances with contents over $15 \%$ on dry basis [19]. In fact, apple pomace (15\% to $20 \%$ of pectin) and citrus peel (30\% to $35 \%$ of pectin), obtained in fruit juice industries, are the two main raw materials used for the industrial extraction of pectins. However, other natural sources with potential in the pectins extraction have been described in literature [15]. For example, plants of Lupinus genus (pectins content 1.5\%-7\% depending on the variety, year, and climatic conditions), burdock from the Arctium genus (pectins content higher than $21 \%$ ) or peach (Persica vulgaris L.) with pectins content up to $10 \%$ have been proposed. 
The diverse nature of the pectic substances has resulted in different extraction methods. Depending on the raw material the extraction methods and further chemical purification treatments are different. This section focuses on natural pectin sources and the associated extraction methods used to produce high added-value products. The most frequent extraction techniques are: (i) conventional solvent extraction based on stirring and heating; (ii) microwave assisted extraction (MAE); (iii) electromagnetic induction (EMI); (iv) ultrasound-assisted extraction (UAE); and (v) enzymatic extraction.

In general terms, pectins are commonly extracted by solvent-liquid methods in acidic aqueous media (nitric, sulfuric, phosphoric or citric acid) at high temperatures due to their availability, applicability and ease of use [20]. Pectins are usually extracted by hot dilute mineral acids at $\mathrm{pH} 1.5-2.5$, taking $2-4 \mathrm{~h}$ with further precipitation with ethanol or isopropyl alcohol, separation to remove impurities, drying, grinding and blending with other additives. The extracted pectins can be categorized into two major types, depending on their DM degree. Factors like $\mathrm{pH}$, temperature, time and solvent:liquid $(\mathrm{S}: \mathrm{L})$ ratio are usually studied to optimize the extraction conditions. Table 1 shows the main extraction methods for natural pectins reported in literature.

Table 1. Natural pectins extracted by solvent extraction methods.

\begin{tabular}{|c|c|c|c|}
\hline Natural Source & Extraction Parameters & Pectin Yield Extraction (\%) & Ref. \\
\hline Okra pods & $\begin{array}{l}\text { Citric and phosphate buffer, } \mathrm{pH} 2 \text { and } 6 \text {, } \\
60 \mathrm{~min}, 80^{\circ} \mathrm{C}, 1: 15 \mathrm{~g} \cdot \mathrm{mL}^{-1}\end{array}$ & $13.3(\mathrm{pH} 2.0) ; 15.7(\mathrm{pH} 6.0)$ & {$[21]$} \\
\hline Durian rinds & $\mathrm{HCl}, \mathrm{pH} 2.8,43 \mathrm{~min}, 86^{\circ} \mathrm{C}, \mathrm{S}: \mathrm{L} 1: 10 \mathrm{~g} \cdot \mathrm{mL}^{-1}$ & 9.1 & {$[22]$} \\
\hline Mango peel & Sulfuric acid in water, $\mathrm{pH} 1.5,2.5 \mathrm{~h}, 90^{\circ} \mathrm{C}$ & $>70$ & [23] \\
\hline \multirow[t]{2}{*}{ Banana peel } & $\begin{array}{l}\text { Citric acid solution, } \mathrm{pH} 2.0,160 \mathrm{~min} \\
87^{\circ} \mathrm{C}, 1: 20 \mathrm{~g} \cdot \mathrm{mL}^{-1}\end{array}$ & 13.89 & {$[24]$} \\
\hline & Citric acid and $\mathrm{HCl}, \mathrm{pH} 1.5,4 \mathrm{~h}, 90{ }^{\circ} \mathrm{C}$ & 16.54 & [25] \\
\hline Tropical fruit peels & $\begin{array}{l}\text { Citric acid, } \mathrm{pH} \text { of } 2,3.3 \text { and } 4.5,120 \mathrm{~min} \text {, } \\
70^{\circ} \mathrm{C}\end{array}$ & $12.56-14.24$ & {$[26]$} \\
\hline Sugar beet pulp & Citric acid, $\mathrm{pH} 1,166 \mathrm{~min}, 99^{\circ} \mathrm{C}, 1: 20 \mathrm{~g} \cdot \mathrm{mL}^{-1}$ & 23.95 & [27] \\
\hline Bagasse and pomace lime fruit & Citric acid, $60 \mathrm{~min}, 90^{\circ} \mathrm{C}, 1: 20 \mathrm{~g} \cdot \mathrm{mL}^{-1}$ & $\begin{array}{c}13.31 \text { (Bagasse); } \\
15.1 \text { (Pomace) }\end{array}$ & {$[28]$} \\
\hline Valencia orange peel & Citric acid extraction, $\mathrm{pH} 1.5,75 \mathrm{~min}, 90^{\circ} \mathrm{C}$ & 16.7 & [29] \\
\hline Watermelon seed & $\mathrm{HCl}, \mathrm{pH} 2,60 \mathrm{~min}, 85^{\circ} \mathrm{C}, 1: 15 \mathrm{~g} \cdot \mathrm{mL}^{-1}$ & 19.75 & {$[30]$} \\
\hline Faba bean hulls & $\mathrm{HCl}, \mathrm{pH} 1.5,80 \mathrm{~min}, 85^{\circ} \mathrm{C}, 1: 25 \mathrm{~g} \cdot \mathrm{mL}^{-1}$ & 15.75 & {$[31]$} \\
\hline $\begin{array}{c}\text { Honeydew melon seeds and } \\
\text { damaged skin }\end{array}$ & $\mathrm{HCl}$ at $\mathrm{pH} 1,80^{\circ} \mathrm{C}$ for $4 \mathrm{~h}$ & 7.9 & {$[32]$} \\
\hline Tomato peel & $\begin{array}{l}\text { Ammonium oxalate and oxalic acid, } 90^{\circ} \mathrm{C} \\
\text { in two extraction steps ( } 24 \text { and } 12 \mathrm{~h} \text { ) }\end{array}$ & 32.0 & {$[33]$} \\
\hline Sunflower head & Sodium citrate, $85^{\circ} \mathrm{C}, 3.5 \mathrm{~h}, 1: 40 \mathrm{~g} / \mathrm{mL}$ & 16.90 & [34] \\
\hline
\end{tabular}

Alba, Laws and Kontogiorgos extracted okra pod pectins at different $\mathrm{pH}$ values (2.0 and 6.0 with $100 \mathrm{mM}$ citric and phosphate buffer, respectively) and examined the effect of the extraction conditions on their molecular and compositional characteristics [21]. Pectins obtained could not be quantitatively recovered in a single extraction step and second extraction was required. They concluded that pectins extracted with citric buffer $(\mathrm{pH} 2.0)$ resulted in slightly lower yields $(13.3 \% \pm 0.3 \%)$ when compared to extraction at $\mathrm{pH} 6.0(15.7 \% \pm 0.2 \%)$. The highest extraction yields were obtained at high temperatures 
and low $\mathrm{pH}$ values due to the cleavage of pectin and other cell wall materials. Furthermore, okra pectins were found to be LM with DM 40.0\% $\pm 1.6 \%$ and $24.6 \% \pm 1.0 \%$ for $\mathrm{pH} 2.0$ and 6.0 , respectively. These results could be attributed to de-esterification process caused by the $\beta$-elimination of the esterified homogalacturonan backbone, removing methyl ester groups and resulting in pectins with lower DM and molecular mass. These pectins can be used as functional ingredients (thickeners, viscosity enhancers, gelling agents and texture modifiers) in the food industry.

Durian (Durio zibethinus) is considered as a high-value fruit due to its distinct flavor and unique taste, but its processing generates large amounts of waste and by-products rich in polysaccharides. A second-order polynomial equation using a three-level Box-Behnken response design to optimize the extraction conditions of pectins from Durian residues was recently proposed [22]. Those authors studied the influence of four variables: S:L ratio $\left(5-15 \mathrm{~g} \cdot \mathrm{mL}^{-1}\right), \mathrm{pH}(2-3)$, extraction time (20-60 min) and extraction temperature $\left(75-95^{\circ} \mathrm{C}\right)$ in the pectins extraction yield. The optimum selected conditions were pH 2.8, $43 \mathrm{~min}, 86^{\circ} \mathrm{C}$ and $1: 10 \mathrm{~g} \cdot \mathrm{mL}^{-1} \mathrm{~S}: \mathrm{L}$ ratio, yielding $9.1 \%$ for the extraction efficiency.

Hubert et al. studied the impact of different Mango (M. indica L.) cultivars, technological procedures and ripeness degree on the pectin quality of their peels [23]. They concluded that grinding of mango peels (with particle sizes of $42 \mu \mathrm{m}$ ) significantly enhanced the pectins extraction yield $(70 \%)$ without increasing the impurity contents.

Banana fruit has been considered an excellent source of pectins. A central composite design was used to determine the effect of $\mathrm{pH}(2.0-4.5)$, extraction temperature $\left(70-90^{\circ} \mathrm{C}\right)$ and time $(120-240 \mathrm{~min})$ in the extraction yield of pectins in citric acid solution $(1: 20 \mathrm{w} / \mathrm{v})$ under stirring (150 rpm) [24]. High temperatures and $\mathrm{pH}$ values resulted in higher extraction yields with a decrease in DM from $79 \%$ to $43 \%$. The optimum conditions for pectins extraction were $87^{\circ} \mathrm{C}, 160 \mathrm{~min}$ and $\mathrm{pH} 2.0$ with extraction yield $13.9 \%$. Castillo-Israel et al. proved that banana peel waste could be a promising source of pectins with extraction yield $17.0 \%$ and $\mathrm{DM} 75.0 \%$ by using $\mathrm{HCl}(0.5 \mathrm{~N}, \mathrm{pH} 1.5)$ and citric acid $(0.5 \mathrm{~N}, \mathrm{pH} 1.7)$ at $90{ }^{\circ} \mathrm{C}$ for $4 \mathrm{~h}$ [25]. Other agricultural residues used as pectins sources are peels of Yellow passion fruit (Passiflora edulis var. flavicarpa), red dragon fruit (Hylocereus polyrhizus) and soursop (Annona muricata L.) [26]. Peels of yellow passion fruit and dragon fruit gave pectins yield of $14.2 \%$ and $12.6 \%$ with $\mathrm{DM} 55.5 \%$ and $47.9 \%$ at $\mathrm{pH}=2.4$ and extraction times 58 and $65 \mathrm{~min}$, respectively. It was concluded that the soursop peels are not suitable by their low pectins yield (lower than $6 \%$ ). In contrast, the extraction of sugar beet pulp pectins in citric acid at $99{ }^{\circ} \mathrm{C}$ and $166 \mathrm{~min}$ at $\mathrm{pH}=1.0$ and $\mathrm{S}: \mathrm{L}$ ratio 20 allowed the maximum extraction yield (23.9\%) [27].

Bagasse and pomace of Mexican lime fruit have been proposed as pectins sources with S:L ratio 1:20, citric acid $1 \%$ at $90{ }^{\circ} \mathrm{C}$ for $60 \mathrm{~min}$ with yields of 13.3 and $15.1 \%$, respectively [28]. Pectins yield extraction from Valencia orange peels was carried out by using citric acid solution at $90{ }^{\circ} \mathrm{C}$ for $75 \mathrm{~min}$ and $\mathrm{pH} 1.5$ yielding acceptable pectins extraction (16.7\%) [29]. Korish reported the use of the Citrullus lanatus var. Colocynthoides watermelon seeds as source of pectins [30]. The optimum yield was obtained with acidic water solution $\left(\mathrm{HCl}, \mathrm{pH} 2.0, \mathrm{~S}: \mathrm{L}\right.$ ratio $1: 15$ and $85^{\circ} \mathrm{C}$ ), for 60 min yielding pectins extraction efficiency of $16.7 \%$. This waste was proposed as raw material for the production of useful biomaterials and chemicals. These authors also studied the potential use of bean hulls as pectins source [31]. The maximum yield of the extracted pectins was not coincident with the highest esterification degree with the maximum yield (15.7\%) recorded at $\mathrm{pH} 1.5$ and $85^{\circ} \mathrm{C}$ for 80 min and S:L 
ratio 1:25; while the highest degree of esterification (54.6\%) occurred at $\mathrm{pH} 2.5$ and $90{ }^{\circ} \mathrm{C}$ for $60 \mathrm{~min}$. Therefore, it was concluded that the yield of pectins was variable with the extraction conditions.

Seeds and damaged skin of fresh honeydew melon (Cucumis melo Inodorus) were proposed as other pectins sources with acceptable efficiencies (7.9\%) in $\mathrm{HCl}$ at $\mathrm{pH}=1.0$ [32]. Pectins from tomato (Lycopersicum esculentum) peels were also extracted under reflux at $90{ }^{\circ} \mathrm{C}$ with ammonium oxalate $\left(16 \mathrm{~g} \cdot \mathrm{L}^{-1}\right)$ and oxalic acid $\left(4 \mathrm{~g} \cdot \mathrm{L}^{-1}\right)$ in two extraction steps (24 and $12 \mathrm{~h}$ respectively) [33]. The highest pectins yields were $32.6 \%$ and $31.9 \%$ in two batches, but the pectin quality was low in the second extraction step. Kang et al. extracted pectins from sunflower heads (SFHP) with sodium citrate at $85{ }^{\circ} \mathrm{C}$ and $\mathrm{S}: \mathrm{L}$ ratio $1: 40$ [34]. The content in uronic acid was used in this study as the indicator of the pectin extraction yield by using the carbazole colorimetric method with a maximum yield in uronic acid of $16.9 \%$.

Giosafatto et al. recently reported the production of an edible hydrocolloid film made by using Citrus pectin and the protein phaseolin crosslinked by microbial transglutaminase, an enzyme able to covalently modify proteins by formation of isopeptide bonds between glutamine and lysine residues [35,36]. These authors included different biopolymer matrices in their formulations, including chitosan [37,38] and whey proteins [39].

In general terms, it can be concluded that the combination of high temperatures, times and solvents volume resulted in the recovery of pure pectins. However, two problems in the pectins extraction were described, since long heating times resulted in ruptures of the pectin chains leading to difficulties in pectin isolation, while acid extraction may result in corrosion and pollution whereas the alkaline extraction reduces the chain of galacturonic acid by beta-elimination [20]. Therefore, innovative methods such as MAE, EMI, UAE and enzymatic treatment have been proposed to counteract these effects. Table 2 summarizes the most recent trends on the application of these methods for pectins extraction.

Table 2. Innovative extraction methods for pectins.

\begin{tabular}{|c|c|c|c|c|}
\hline $\begin{array}{l}\text { Extraction } \\
\text { Method }\end{array}$ & Natural Source & Extraction Parameters & $\begin{array}{c}\text { Pectin Yield } \\
\text { Extraction (\%) }\end{array}$ & Ref. \\
\hline \multirow{6}{*}{ MAE } & \multirow{2}{*}{ Dragon fruit peel } & $400 \mathrm{~W}, 45^{\circ} \mathrm{C}, 20 \mathrm{~min}, 24 \mathrm{~g} \cdot \mathrm{mL}^{-1}$ & 7.5 & [40] \\
\hline & & $\mathrm{HCl}, \mathrm{pH} 2.07,800 \mathrm{~W}, 65 \mathrm{~s}, 66.6 \mathrm{~g} \cdot \mathrm{mL}^{-1}$ & 18.57 & {$[41]$} \\
\hline & $\begin{array}{l}\text { Bagasse and pomace } \\
\text { of Mexican lime fruit }\end{array}$ & Citric acid, $800 \mathrm{~W}, 120^{\circ} \mathrm{C}, 5 \mathrm{~min}, 1: 30 \mathrm{~g} \cdot \mathrm{mL}^{-1}$ & $\begin{array}{c}16.9 \text { (Bagasse); } \\
8.4 \text { (Pomace) }\end{array}$ & [28] \\
\hline & Pomelo peel & Tartaric acid solution, $\mathrm{pH} 1.5,660 \mathrm{~W}, 9 \mathrm{~min}, 1: 40 \mathrm{~g} \cdot \mathrm{mL}^{-1}$ & 23.83 & [42] \\
\hline & Mango peel & Aqueous solution, $\mathrm{pH} 2.7,413 \mathrm{~W}, 134 \mathrm{~s}, 1: 18 \mathrm{~g} \cdot \mathrm{mL}^{-1}$ & 28.86 & [43] \\
\hline & Papaya peel & Aqueous solution, $512 \mathrm{~W}, \mathrm{pH} 1.8,140 \mathrm{~s}, 1: 15 \mathrm{~g} \cdot \mathrm{mL}^{-1}$ & 25.41 & [44] \\
\hline EMI & Citrange albedos & Aqueous solution, $\mathrm{pH} 1.2$ with $\mathrm{H}_{2} \mathrm{SO}_{4}, 80^{\circ} \mathrm{C}, 90 \mathrm{~min}$ & 29 & {$[45]$} \\
\hline \multirow{4}{*}{ UAE } & Pomegranate peel & Aqueous solution, $\mathrm{pH} 1.27,61.9^{\circ} \mathrm{C}, 28.31 \mathrm{~min}, 1: 17.52 \mathrm{~g} \cdot \mathrm{mL}^{-1}$ & 24.18 & [46] \\
\hline & Sisal fiber & Aqueous solution, $61 \mathrm{~W}, 50^{\circ} \mathrm{C}, 26 \mathrm{~min}, 1: 28 \mathrm{~g} \cdot \mathrm{mL}^{-1}$ & 29.32 & [47] \\
\hline & Sugar beet pulp & Aqueous solution, $10.70 \mathrm{MPa}, 120.72{ }^{\circ} \mathrm{C}, 30.49 \mathrm{~min}, 44.0 \mathrm{~g} \cdot \mathrm{mL}^{-1}$ & 24.63 & [48] \\
\hline & Grapefruit peel & $\begin{array}{c}\text { Deionized water, } \mathrm{HCl}, \mathrm{pH} 1.5,12.56 \mathrm{~W} / \mathrm{cm}^{2}, 66.7^{\circ} \mathrm{C}, \\
27.9 \mathrm{~min}, 1: 50 \mathrm{~g} \cdot \mathrm{mL}^{-1}\end{array}$ & 27.34 & [49] \\
\hline \multirow[t]{2}{*}{ Enzymes } & $\begin{array}{l}\text { Gold kiwifruit pulp, } \\
\text { skin and seed }\end{array}$ & \multirow{2}{*}{$\begin{array}{c}\text { Purified water, } \mathrm{pH} 3.7,25^{\circ} \mathrm{C}, 30 \mathrm{~min} \text {, Celluclast } 1.5 \mathrm{~L} \\
\text { enzyme }\left(1.05 \mathrm{~mL} \cdot \mathrm{kg}^{-1}\right), 1: 3 \mathrm{~g} \cdot \mathrm{mL}^{-1}\end{array}$} & 2.14 & {$[50]$} \\
\hline & Gold kiwifruit pomace & & 4.5 & {$[51]$} \\
\hline
\end{tabular}


MAE is an extraction technique that uses microwave power to heat samples in solution by enhancing the mass transfer rate of the solutes from the vegetable raw materials to solvents. Two main mechanisms allows the pectin extraction by MAE, i.e., the rapid increase in temperature, which reduces the emulsion viscosity and breaks the chemical bonds in the raw material structure, and the molecular rotation due to the electrical charges of molecules, resulting in enhanced movement of ions which increase the efficiency of the extraction process [41]. MAE has been reported as the preferred extraction method of pectins from natural sources such as dragon fruit peels [40,41], bagasse and pomace obtained from Mexican lime fruit [28], pomelo [42], mango [43] and papaya peels [44] under different operation conditions. MAE conditions are dependent on different factors, such as microwave power, $\mathrm{pH}$, time and $\mathrm{S}: \mathrm{L}$ ratio. MAE methods show significant advantages over the conventional extraction techniques, such as the reduction in the amount of the extraction solvents, low energy consumption, high recoveries, good reproducibility, short extraction times (minutes rather than hours) and minimal sample manipulation.

Since these variables should be optimized for the development of every method, response surface methodologies (RSM) are used to study their interactive effects on pectins extraction with good correlation between experimental data and the predicted values. Table 2 summarizes the proposed MAE conditions to obtain maximum pectins extraction yields from natural sources. The most usual procedure includes the use of Box-Behnken experimental designs (BBD) or central composite designs (CCD). Good results were reported for the extraction of target compounds, such as antioxidants from almond skin [52], peanut skin [53] and batata leaves [54], highlighting the potential of MAE as a promising extraction method for pectins.

The use of EMI methods involving mixing, heating and maintenance of samples in an acidic medium to extract pectins has been also proposed. Zouambia et al. introduced a new approach for pectins extraction from citrange albedos [45]. In this study, the extraction yield, composition and physico-chemical characteristics of pectins extracted by electromagnetic induction heating were studied and compared with those obtained by direct boiling. EMI methods were also evaluated at different extraction times and power levels. A considerable reduction in time was observed by using EMI, since only 30 min were necessary to obtain pectins extraction yield (24\%) similar to those obtained with conventional heating methods for $90 \mathrm{~min}$. This innovative method can be suggested as an alternative for pectins extraction with short times, good yield and maintaining the main physico-chemical properties of pectins.

UAE is a process that uses acoustic energy and selected solvents to extract specific compounds from various matrices in relatively short times giving high yields. The mechanism of UAE is based on the interaction of the ultrasound waves and the solvent molecules allowing the acoustic cavitation and the disruption of cell walls with enhanced mass transfer across the cell membranes [20]. High efficiencies were recently reported for the UAE of pectins from several agricultural wastes, such as pomegranate peel [46] and sisal fiber [47]. In both cases, BBD was successfully used as valuable multivariate technique to evaluate the relationship between variables, helping to determine the accurate optimum values of all the experimental parameters with a reduced number of experiments [55]. In pomegranate peel, the effects of $\mathrm{pH}, \mathrm{S}: \mathrm{L}$ ratio, extraction time and temperature on the recovery of pectins were studied [46]. The maximum extraction yields were determined at $\mathrm{pH}=1.27 ; 28.3 \min 1: 17.5 \mathrm{~g} \cdot \mathrm{mL}^{-1} \mathrm{~S}: \mathrm{L}$ ratio and $61.9{ }^{\circ} \mathrm{C}$ resulting in yield extraction of $24.2 \%$. In sisal fibers, the extraction conditions were also optimized [47]. The analysis of variance showed that the contribution of a quadratic model was significant for the pectins extraction yield. The optimal extraction condition were $61 \mathrm{~W}, 1: 28 \mathrm{~g} \cdot \mathrm{mL}^{-1}$ 
$\mathrm{S}: \mathrm{L}$ ratio, $26 \mathrm{~min}$ and $50{ }^{\circ} \mathrm{C}$ resulting in pectins yield of $29.3 \%$. Therefore, UAE was proposed as an alternative method to extract pectins from sisal waste with the advantages of lower extraction temperatures and energies and shorter extraction times.

Several authors have combined UAE with other extraction techniques. Pectin-enriched materials obtained from sugar beet pulp wastes were extracted by UAE combined with subcritical water by using the RSM methodology [48]. The highest extraction yields (24.6\%) were obtained at pressure $10.70 \mathrm{MPa}$, $120.7^{\circ} \mathrm{C}, 30.5 \mathrm{~min}$ and $\mathrm{S}: \mathrm{L}$ ratio $44.0 \mathrm{~g} \cdot \mathrm{mL}^{-1}$.

The effect of the extraction temperature and sonication time is essential for UAE, but not much published work has focused on the optimization of UAE conditions and exploration of the combined effects of these variables in the pectins extraction. Wang et al. used RSM to study the extraction of grapefruit peel pectins by UAE, evaluating the combined effects of ultrasound power and extraction time and temperature on the extraction yield in $\mathrm{HCl}$ aqueous solutions $(\mathrm{pH}=1.5)$ [49]. This study also compared UAE results with those obtained with conventional extraction methods using the same solvent at $80{ }^{\circ} \mathrm{C}$ for $90 \mathrm{~min}$. UAE provided extraction yields of $16.3 \%$ at low temperatures and short times. In summary, UAE could be considered as an efficient and economic technique to extract pectins from plant resources.

All these methods have in common the use of diluted acid solutions, but in some cases non-solvent methods are preferred in food products. Enzymatic methods represent an innovative and clean alternative for the "green" extraction of pectins reducing water pollution and waste generation. These methods are based on the degradation of pectins by selective depolymerisation or their isolation by breaking the plants cell wall [20]. Only few works have reported the use of these methods by comparing the enzymatic extraction of pectins obtained from gold kiwifruit wastes at different stages of maturity with other extraction methods [50,51]. In both cases, the enzymatic treatment was conducted at $25^{\circ} \mathrm{C}$ for $30 \mathrm{~min}$ with a Celluclast $1.5 \mathrm{~L}\left(1.05 \mathrm{~mL} \cdot \mathrm{kg}^{-1}\right)$ at $\mathrm{pH} 3.70 \pm 0.05$. These methods showed relative low yields ( $2.14 \%$ for peel, skin and seeds and $4.5 \%$ for pomace) when compared to acid/water extraction methods. Nevertheless, the advantages of enzymatic methods, i.e., low temperatures that contribute to avoid degradation of pectins and low cost, make this method a promising alternative that deserves further study.

\section{Recent Trends in the Use of Pectin Edible Coatings}

Edible coatings are currently used in highly perishable foodstuff to protect their nutritional and organoleptic properties by their potential to extend shelf-life and reducing the negative effects caused by processing, such as enzymatic browning, texture breakdown and off-flavors development [56,57]. In addition, edible coatings may contribute to the reduction of gas exchange, moisture and solute migration as well as to the reduction of the respiration and oxidation reaction rates and the decrease of the risk of pathogens growth on food surfaces during storage [58].

The selection of the most adequate edible materials for this purpose depends on different factors, such as cost, availability, mechanical properties, transparency, brightness, gas barrier effects and resistance to water and microorganisms. The selection is also influenced by the coating processing conditions ( $\mathrm{pH}$, type of solvent, temperature), type and concentration of additives (plasticizers, emulsifiers or cross-linking agents) and by the presence of active compounds in the edible matrix (antimicrobials, antioxidants, texture enhancers or nutraceuticals) [56,58]. 
Plasticizers, such as glycerol or sorbitol, in edible coating formulations play the role of improving coatings flexibility by reducing the number of internal hydrogen bonds between polymer chains and by increasing the free volume in the matrix to permit oxygen and water vapor diffusion through the coating film. Emulsifiers are usually added into coating formulations to improve wettability, stability and adhesion to the food surface, while cross-linking agents are necessary to react with carbohydrates forming a solid polymeric matrix upon the food. In particular, the gelation of low-methoxyl pectins takes place in the presence of multivalent metal cations, such as calcium, due to their electrostatic interactions with the opposite charged cavities formed by polymer chains [59-61].

The most recent trends in the field of pectins coating applications include the shelf-life extension of fresh-cut highly perishable food, the application of pectin coatings as pre-frying treatment to reduce the oil consumption in deep-fat fried products and the use as pre-dried treatments to improve the retention of nutrients and quality characteristics of dehydrated and lyophilized food.

\subsection{Shelf-life Extension of Fresh-cut Fruits and Vegetables}

Consumers usually accept fresh food on the basis of their appearance and organoleptic characteristics, but their shelf-life is usually low, representing a clear problem for their commercial distribution. The increasing interest for fresh-cut fruits consumption has resulted in the development of physical technologies to extend their shelf-life [62]. The traditional method of storage at low temperatures to slow down the fruits metabolism can be used in combination with other strategies, being modified atmosphere packaging (MAP), thermal treatments (blanching and heat-shock), irradiation, UV light and edible films and coatings the most common preservation methods [63].

Among all these methods, the direct application of edible coatings onto the surface of fresh-cut horticultural products is one of the most studied possibilities. In particular, pectin coatings have been widely evaluated for this purpose by their good oxygen and carbon dioxide barrier, their ability to retard lipid migration and moisture loss while maintaining the sensory and quality of food. Low-methoxyl pectins are mostly used as edible coatings by their ability to form firm gels at low $\mathrm{pH}$ in the presence of calcium cations, promoting higher firmness and structural integrity while reducing water vapor permeability $[64,65]$. Table 3 summarizes the most recent reports on applications of edible pectin-based coatings to extend shelf-life in fresh fruits and vegetables.

In this context, low methoxyl edible pectins coated onto fresh-cut melon improved water vapor resistance, preventing dehydration and maintaining the initial firmness during storage (15 days at $4{ }^{\circ} \mathrm{C}$ ) by using calcium chloride as cross-linking agent and sunflower oil as lipid source in the preparation of the film-forming emulsion. This edible coating did not reduce the microbiological growth, but could help to decrease the wounding stress of fresh-cut melon, providing antioxidant properties and maintaining quality attributes [66]. 
Table 3. Pectin-based coatings to extend shelf-life of fresh fruits and vegetables.

\begin{tabular}{|c|c|c|c|c|}
\hline Coating & Active Agent & Food Matrix & Effect & Ref. \\
\hline $\begin{array}{l}\text { Low methoxyl pectin }(2 \%) \text {, } \\
\text { glycerol, sunflower oil, } \mathrm{CaCl}_{2}\end{array}$ & - & Melons (Cucumis melon L.) & $\begin{array}{l}\text { Antioxidant properties maintaining } \\
\text { quality attributes }\left(4^{\circ} \mathrm{C}, 15 \text { days }\right)\end{array}$ & {$[66]$} \\
\hline Pectin (3\%), sorbitol, beeswax & - & Mangoes (cv. Ataulfo) & $\begin{array}{l}\text { Reduction of physiological changes, } \\
\text { respiration rates and weight loss } \\
\text { (15 days, room temperature) }\end{array}$ & {$[67]$} \\
\hline Pectin (3\%), sorbitol, beeswax & - & Avocados & $\begin{array}{l}\text { Reduction of firmness, color, } \\
\text { respiration rates and moisture loss } \\
\left(10^{\circ} \mathrm{C}, 1 \text { month }\right)\end{array}$ & {$[68]$} \\
\hline $\begin{array}{l}\text { Osmotic dehydration } \\
\text { (with } 0.5 \% \text { calcium lactate) }+ \\
\text { pectin coating }(1 \%)\end{array}$ & - & $\begin{array}{l}\text { Ripe Melons (Cucumis } \\
\text { melon cv. inodorus) }\end{array}$ & $\begin{array}{l}\text { Reduction of respiration rate } \\
\text { maintaining sensory properties } \\
\text { and quality parameters }\left(5^{\circ} \mathrm{C} \text {, }\right. \\
80 \% \mathrm{RH}, 14 \text { days })\end{array}$ & {$[69]$} \\
\hline $\begin{array}{l}\text { Pectin }(2 \%)+\text { glycerol combined } \\
\text { with MAP }\end{array}$ & - & $\begin{array}{l}\text { Nectarines (Prunus } \\
\text { persica L. cv. Babygold) }\end{array}$ & $\begin{array}{l}\text { Texture, color and hygienic quality } \\
\left(3^{\circ} \mathrm{C}, 7 \text { days }\right)\end{array}$ & {$[62]$} \\
\hline $\begin{array}{l}\text { Multi-layered alginate (1\%)- } \beta \text { - } \\
\text { CD-trans }(2 \%) / \text { pectin }(2 \%) \\
\text { Calcium lactate }\end{array}$ & $\begin{array}{l}\text { trans-cinnamaldehyde } \\
\text { encapsulated in } \beta \text {-Cyclodextrins }\end{array}$ & Watermelon (C. lanatus) & $\begin{array}{l}\text { Antimicrobial activity maintaining } \\
\text { quality and sensory attributes } \\
\left(4^{\circ} \mathrm{C}, 12 \text { days }\right)\end{array}$ & {$[70]$} \\
\hline $\begin{array}{l}\text { Multi-layered chitosan }(2 \%)-\beta- \\
\text { CD-trans }(1 \%) / \text { pectin }(1 \%) \mathrm{CaCl}_{2}\end{array}$ & $\begin{array}{l}\text { trans-cinnamaldehyde } \\
\text { encapsulated in } \beta \text {-Cyclodextrins }\end{array}$ & Cantaloupe melon & $\begin{array}{l}\text { Antimicrobial activity maintaining } \\
\text { quality and sensory attributes } \\
\left(4^{\circ} \mathrm{C}, 9 \text { days }\right)\end{array}$ & {$[71]$} \\
\hline $\begin{array}{l}\text { Multi-layered chitosan }(2 \%)-\beta- \\
\text { CD-trans }(1 \%) / \text { pectin }(2 \%) \mathrm{CaCl}_{2}\end{array}$ & $\begin{array}{l}\text { trans-cinnamaldehyde } \\
\text { encapsulated in } \beta \text {-Cyclodextrins }\end{array}$ & $\begin{array}{l}\text { Papaya fruits (Carica } \\
\text { papaya L. cv Maradol) }\end{array}$ & $\begin{array}{l}\text { Antimicrobial activity maintaining } \\
\text { quality and sensory attributes } \\
\left(4^{\circ} \mathrm{C}, 15 \text { days }\right)\end{array}$ & {$[72]$} \\
\hline Pectin (2\%), glycerol, $\mathrm{CaCl}_{2}$ & $N$-acetylcysteine Glutathione & Pears (Pyrus communis L.) & $\begin{array}{l}\text { Antibrowning, antimicrobial, } \\
\text { antioxidant maintaining sensory } \\
\text { attributes }\left(4^{\circ} \mathrm{C}, 14 \text { days }\right)\end{array}$ & {$[73]$} \\
\hline Pectin $(3.5 \%)$, glycerol & $\begin{array}{l}\text { Sodium benzoate; } \\
\text { Potassium sorbate }\end{array}$ & $\begin{array}{l}\text { Strawberries (Fragaria } \\
\text { ananassa cv. Albion) }\end{array}$ & $\begin{array}{l}\text { Antimicrobial activity maintaining } \\
\text { physico-chemical and sensory } \\
\text { attributes }\left(4^{\circ} \mathrm{C}, 15 \text { days }\right)\end{array}$ & {$[74]$} \\
\hline Pectin (2\%), glycerol, $\mathrm{CaCl}_{2}$ & $\begin{array}{l}\text { Apple fiber; Inulin; } \\
\text { Ascorbic acid }\end{array}$ & “Golden delicious" apples & $\begin{array}{l}\text { Nutritional value maintaining } \\
\text { firmness, color and antioxidant } \\
\text { activity }\left(4^{\circ} \mathrm{C}, 7 \text { days) }\right.\end{array}$ & {$[75]$} \\
\hline Pectin $(2 \%) \mathrm{CaCl}_{2}$ & Eugenol Citral; Ascorbic acid & Strawberries & $\begin{array}{l}\text { Antimicrobial, antioxidant, } \\
\text { antibrowning activities maintaining } \\
\text { sensory properties }\left(0.5^{\circ} \mathrm{C}, 7 \text { days }\right)\end{array}$ & {$[76]$} \\
\hline Pectin $(1 \%) \mathrm{CaCl}_{2}$ & Eugenol Citral; Ascorbic acid & Raspberries & $\begin{array}{l}\text { Antimicrobial, antioxidant, } \\
\text { antibrowning activities maintaining } \\
\text { sensory properties }\left(0.5^{\circ} \mathrm{C}, 7 \text { days }\right)\end{array}$ & {$[77]$} \\
\hline Pectin $(3 \%)+$ glycerol & Cinnamon leaf essential oil & Peach (Prunus persica) & $\begin{array}{l}\text { Antimicrobial, antioxidant } \\
\text { activity. Odor acceptability up to } \\
10 \text { days }\left(5^{\circ} \mathrm{C}\right)\end{array}$ & {$[78]$} \\
\hline
\end{tabular}


Another study reported the use of pectin coatings to restrict the loss of moisture from avocados during storage, decreasing the $\mathrm{O}_{2}$ absorption and slowing down the respiration rate [68]. The delay in changes on texture and color was observed, concluding that pectin coatings could extend the shelf-life of avocados to over a month at $10{ }^{\circ} \mathrm{C}$. Similar results were reported by Moalemiyan et al. in fresh-cut mangoes coated with pectins, which remained in acceptable quality conditions for over two weeks by applying the optimized coating formulation: pectin (1.3\% in water), sorbitol (28\%) as plasticizer and beeswax (23\%) based on pectins dry weight [67]. Authors reported that some optimization of the coating formulation was necessary to prevent the off-flavor development and the anaerobic respiration. A balance between gas and water vapor permeability should be achieved, but it is dependent on the respiration rate of each fruit or vegetable.

A recent report highlighted that the combination of osmotic dehydration (in $40^{\circ} \mathrm{Bx}$ sucrose solution containing $0.5 \%$ calcium lactate) and pectins coating (1\%) was a good preservation alternative for fresh-cut melon by reducing the fruit respiration rate and maintaining the organoleptic properties and quality parameters for 14 days of storage at $5{ }^{\circ} \mathrm{C}$ and $80 \% \mathrm{RH}$ [69].

MAP is another popular technique to extend the shelf-life of fresh-cut fruits by decreasing $\mathrm{O}_{2}$ and increasing $\mathrm{CO}_{2}$ levels in the headspace of closed packages, reducing the respiration rate during storage with the positive effect of delaying ageing and senescence [63]. However, anaerobic respiration should be avoided to limit the proliferation of hazardous microorganisms and, consequently, some increase in ethanol production and off-flavors can be observed. In this sense, the combination of low-temperature storage, MAP and edible coatings have shown to be a promising alternative to control respiration of fruits [62]. It was reported that nectarine sections can be stored at $3{ }^{\circ} \mathrm{C}$ for 7 days maintaining texture, color and hygienic quality by using pectin, chitosan and sodium caseinate coatings combined with MAP.

Another current trend in food packaging research is the development of active systems with materials containing active compounds in their composition with the possibilities of release at controlled rate to the food surface during storage, resulting in shelf-life extension [79]. It was stated that pectins edible matrices show excellent performance as carriers for active compounds, such as antioxidants, antimicrobials and texture enhancers. The incorporation of active compounds into edible films and coatings has the main goal to reduce, inhibit or stop the microbial growth in food surfaces. The effect on the permeability and mechanical properties of active agents in coating formulations need further studies $[58,80]$. Herbs and spices are the most common sources of active additives, in particular phenolics, flavonoids and terpenoids [79]. Essential oils derived from plants and their components are also interesting bioactive agents in active packaging formulations. However, their application to packaging of fresh fruits and vegetables is still under investigation by their high volatility, reactivity and strong aroma that could affect the organoleptic characteristics of food. For example, the incorporation of cinnamon leaf essential oil into pectin edible coatings resulted in an effective antimicrobial activity and the enhancing of the antioxidant status of fresh-cut peach, with good acceptation by consumers [78].

The main components of essential oils obtained from herbs and spices have been evaluated as active agents in food packaging applications [79]. Eugenol and citral are examples of active compounds obtained from plant-derived essential oils, since they have been reported as good antimicrobial agents in pectin coatings to extend fresh strawberries and raspberries shelf-life [76,77]. In this context, $\mathrm{N}$-acetylcysteine $(0.75 \% \mathrm{w} / \mathrm{v})$ and glutathione $(0.75 \% \mathrm{w} / \mathrm{v})$ were incorporated into pectin coatings (in the calcium chloride solution) to help in the enzymatic browning control while also retarding the 
microbial growth in fresh-cut pears and contributing to maintain the high antioxidant potential of this fruit without affecting firmness for 14 days at $4{ }^{\circ} \mathrm{C}$ [73]. Sodium benzoate and potassium sorbate are other active compounds successfully incorporated in pectin solutions to form edible coatings [74]. Results showed that pectin active coatings improved the physico-chemical, microbiological and sensory quality (color, flavor, texture and acceptance) of strawberries from 6 (control) to 15 days at $4{ }^{\circ} \mathrm{C}$ and $90 \%$ RH.

A limited number of studies on the effect of the incorporation of nutraceutical compounds into edible coatings to extend food shelf-life while providing nutritional value have been reported. Moreira et al. introduced apple fiber and inulin into pectins solutions as edible coatings in fresh-cut "Golden delicious" apples evaluating the effect on the quality attributes [75]. Ascorbic acid was also added as antioxidant. Results demonstrated that these edible active formulations increased the nutritional value of fresh-cut apples while maintaining the firmness and color and helping to keep their antioxidant potential for seven days of storage at $4{ }^{\circ} \mathrm{C}$.

Multilayer coatings have received recent interest to overcome the problem of the poor adhesion between the commonly hydrophobic coatings and the hydrophilic surface of fruits. In the layer-by-layer technique fruits and vegetables are dipped into different solutions with opposite charged polyelectrolytes with the aim to obtain strong chemical bonds between them [71]. In this context, pectins have been studied in combination with other edible matrices, such as alginate or chitosan. Multilayer coatings were successfully prepared with the layer-by-layer technique by using a solution of sodium alginate containing one antimicrobial agent (trans-cinnamaldehyde encapsulated in $\beta$-cyclodextrins ( $\beta$-CD-trans)) in combination with pectins and calcium lactate solutions to obtain stable and homogeneous coatings [70]. Authors reported that multilayer coatings with $1 \%$ alginate, $2 \% \beta$-CD-trans and $2 \%$ pectins maintained the quality and organoleptic attributes of fresh-cut watermelon while extending the shelf life at $4{ }^{\circ} \mathrm{C}$ from 7 (control) to 12 days. In addition, microbiological analysis demonstrated the effectiveness of the encapsulated agents in the multilayer coatings against microbial growth. The application of multilayer coatings formed by chitosan $(2 \%), 2 \% \beta$-CD-trans and pectins ( $1 \%$ ) (optimum formulation) was reported with the extension of shelf-life of fresh-cut cantaloupe at $4{ }^{\circ} \mathrm{C}$ up to 9 days [71]. Similar multilayer coatings were also successful in prolonging the shelf-life of fresh-cut papaya [72]. In both cases, calcium chloride (2\%) was used as cross-linking agent.

\subsection{Pectin Coatings in Pre-frying Treatments}

Fried foods usually contain a significant amount of saturated and unsaturated fats, in some cases up to $1 / 3$ of the total product mass. This high fats content has been related to obesity and coronary heart diseases. During deep-frying, the internal moisture of food is evaporated while oil is confined to the external surface. These processes are influenced by factors such as oil quality, frying conditions (temperature and time), food composition and pre-frying treatments (blanching and/or drying). The increase in the consumer's interest for more healthy food products has led to the trend of reducing lipid uptake in fried-food products while maintaining acceptable organoleptic characteristics. Edible coatings prepared from food hydrocolloids, such as cellulose and derivatives, gums, alginate, whey protein, albumin or pectins have been studied for such purpose. The high water absorption capacity and retention 
of the original food firmness of these coatings decrease the moisture loss by evaporation, reducing lipid uptake [56].

In the case of pectin coatings, few investigations have been reported. One of them studied the influence of sunflower head pectin and calcium chloride on the oil absorption in fried-potato chips [16]. Authors concluded that coatings prepared with $1 \%(\mathrm{w} / \mathrm{v})$ pectins solutions induced by $\mathrm{CaCl}_{2}\left(<0.1 \mathrm{~mol} \cdot \mathrm{L}^{-1}\right)$ effectively decreased the lipid uptake by about 30\%. These authors also observed that the $\mathrm{CaCl}_{2}$ concentration influenced significantly on the brittleness and crispiness of coated chips but the consumer's acceptation was still high.

In another study, the combination of carboxymethyl cellulose (CMC) and pectins $(0.5$ and $1 \% \mathrm{w} / \mathrm{w}$ respectively) was used as one layer in a double coating, formed by guar and xantham gums $(1 \% \mathrm{w} / \mathrm{w})$, or in a three-multilayer coating with $\mathrm{CMC} 1 \%(\mathrm{w} / \mathrm{w})$ as the third layer [81]. Those authors recommended the CMC-pectin mixture for single-layer coatings in French-fries since this combination leads to the lowest lipid uptake. Further reductions in the oil absorption were observed in fried food coated with multilayer systems, but the high moisture content of the final products led to the decrease in the crunchiness and loss of acceptance by consumers.

Other authors observed that the application of pectin coatings $(2 \% \mathrm{w} / \mathrm{v})$ reduced significantly the acrylamide formation in banana chips (around 33\%), while helping to slightly improve the organoleptic attributes and crunchiness of the final product [82]. In addition, a synergic effect of the combination of pectin edible coatings and blanching treatments at 90 or $100^{\circ} \mathrm{C}$ for $1 \mathrm{~min}$ was observed, resulting in higher acrylamide reduction in fried-banana chips up to $91.9 \%$ and $90.8 \%$, respectively. In summary, all these results indicate that the use of pectin coatings in pre-frying treatments is a promising process to reduce the lipid uptake and acrylamide content in potato and banana chips, respectively.

\subsection{Pectin Coating as Pre-drying Treatment}

Drying has been traditionally applied as a method of preservation in fruits and vegetables by reduction of their moisture content, decreasing the action of enzymes and preventing the microbial growth. However, this method implies important physical changes in color and texture, as well as chemical modifications related to the degradation of bioactive compounds sensitive to oxygen, light and heating, such as vitamins, antioxidants or minerals. Edible coatings have been proposed as a possibility to prevent the nutrients loss while improving the organoleptic quality of dried products after different pre-treatments, such as blanching and osmotic dehydration [83].

Some authors have recently reported that pectin coatings on papaya slices increased the moisture diffusion coefficient due to the hydrophilic character of pectins while enhancing the retention of vitamin $\mathrm{C}$, resulting in a significant protective effect against nutritional losses [84]. Pectin coatings were also applied to osmotic dehydrated pineapple in sucrose (50\%)/calcium lactate $(4 \%) /$ ascorbic acid $(2 \%)$ solutions before the application of the hot-air-drying method [85]. Results showed that pectin edible coatings were effective as oxygen barrier and did not affect the drying efficiency and the water diffusion coefficient. However, dried pineapples coated with pectins showed high retention of vitamin $\mathrm{C}$ and slightly changed their lightness. Pectin-based coatings $(2 \% \mathrm{w} / \mathrm{w})$ with and without vitamin $\mathrm{C}(1 \% \mathrm{w} / \mathrm{w})$ were also applied to papaya slices before air-drying without reducing the efficiency of the dehydration process [86]. Authors observed that the incorporation of vitamin $\mathrm{C}$ on pectin coatings reduced its 
retention in dried samples after 30 days of storage, while increased significantly the vitamin $\mathrm{C}$ content in the final product. In addition, sensorial analysis confirmed that the pectin + vitamin $\mathrm{C}$ coating can be used as pre-drying treatment of papaya slices.

A combination of pectins (1.5\%), CMC (1.5\%) and ascorbic acid (0.6\%) was used as edible coating of quince slices prior to their osmotic dehydration, with a subsequent hot-air-drying process [87]. In a first step, the composition of the osmotic solution was optimized (fructose $47.7 \%, \mathrm{CaCl}_{2} 4 \%$ and citric acid 3.5\%) and authors reported the important effect of the fructose concentration on water loss. Pectin-CMC-based coatings increased the porosity of the quince dried structure, while the osmotic dehydration increased the collapse of their porous structure. These authors concluded that the decrease observed on the final product firmness could be due to the plasticizing effect of low molecular mass components, which were absorbed from the coating and osmotic solutions.

In summary, all these results suggest that pectin-based coatings can be effectively used as a valid pre-drying treatment constituting a promising alternative to improve the retention of nutrients and quality characteristics of dehydrated food, also opening the possibilities to carry other active additives and nutrients.

\section{Conclusions}

Much work has been recently carried out to propose new formulations of edible coatings based on pectins to be applied in the protection of fresh food, improving organoleptic and nutritional characteristics and extending shelf-life. Despite the fact that recent studies have reported significant improvements in specific applications of these formulations, there is still a large amount of work to be performed since some of the most remarkable improvements are not yet experimentally attained or reproducible at large scale. In general terms, there is still a need for a better understanding of the composition-structure-processing-properties relationships in edible films based on pectins for food packaging, both at the laboratory and industrial scale. Moreover, since many of the studies related to this issue have been carried out using some basic pectins already in the market, there is still a lot of room for variation and maturation in the development of edible coatings for application in food packaging.

\section{Author Contributions}

All authors performed the literatura survey and wrote the paper.

\section{Conflicts of Interest}

The authors declare no conflict of interest.

\section{References}

1. Advancing Sustainable Materials Magement: Facts and Figures 2013. Available online: http://www.epa.gov/wastes/nonhaz/municipal/pubs/2013_advncng_smm_rpt.pdf (accessed on 25 September 2015).

2. Collection and transport. Waste Management World Homepage. Available online: http://www.waste-management-world.com/collection-transport (accessed on 25 September 2015). 
3. Jamshidian, M.; Tehrany, E.A.; Imran, M.; Jacquot, M.; Desobry, S. Poly-lactic acid: Production, applications, nanocomposites, and release studies. Compr. Rev. Food Sci. Food Saf. 2010, 9, 552-571.

4. Martucci, J.F.; Ruseckaite, R.A. Biodegradable three-layer film derived from bovine gelatin. J. Food Eng. 2010, 99, 377-383.

5. Kechichian, V.; Ditchfield, C.; Veiga-Santos, P.; Tadini, C.C. Natural antimicrobial ingredients incorporated in biodegradable films based on cassava starch. LWT-Food Sci. Technol. 2010, 43, 1088-1094.

6. Arzu, A.B.; Tulay, O.; Oya, I.S.; Lutfiye, Y.E. The utilisation of microbial poly-hydroxy alkanoates (PHA) in food industry. Res. J. Biotechnol. 2010, 5, 76-79.

7. Ahmed, J.; Varshney, S.K. Polylactides - Chemistry, properties and green packaging technology: A review. Int. J. Food Prop. 2011, 14, 37-58.

8. Auras, R.; Harte, B.; Selke, S. An overview of polylactides as packaging materials. Macromol. Biosci. 2004, 4, 835-864.

9. Anuradha, K.; Padma, P.N.; Venkateshwar, S.; Reddy, G. Fungal isolates from natural pectic substrates for polygalacturonase and multienzyme production. Indian J. Microbiol. 2010, 50, 339-344.

10. Lopes da Silva, J.A.; Rao, M.A. Food Polysaccharides and Their Applications, 2nd ed.; Taylor \& Francis: Abingdon, UK, 2006.

11. Kohli, P.; Gupta, R. Alkaline pectinases: A review. Biocatal. Agric. Biotechnol. 2015, 4, 279-285.

12. Pedrolli, D.B.; Monteiro, A.C.; Gomes, E.; Carmona, E.C. Pectin and pectinases: Production, characterization and industrial application of microbial pectinolytic enzymes. Open Biotechnol. J. 2009, 3, 9-18.

13. Ridley, B.L.; O’Neill, M.A.; Mohnen, D. Pectins: Structure, biosynthesis, and oligogalacturonide-related signaling. Phytochemistry 2001, 57, 929-967.

14. Caffall, K.H.; Mohnen, D. The structure, function, and biosynthesis of plant cell wall pectic polysaccharides. Carbohydr. Res. 2009, 344, 1879-1900.

15. Ovodov, Y.S. Current views on pectin substances. Russ. J. Bioorg. Chem. 2009, 35, 269-284.

16. Hua, X.; Wang, K.; Yang, R.; Kang, J.; Yang, H. Edible coatings from sunflower head pectin to reduce lipid uptake in fried potato chips. LWT-Food Sci. Technol. 2015, 62, 1220-1225.

17. Ciolacu, L.; Nicolau, A.I.; Hoorfar, J. Global Safety of Fresh Produce. A Handbook of Best Practice, Innovative Commercial Solutions and Case Studies; Woodhead Publishing Limited: Sawston, UK, 2014.

18. Dhanapal, A.; Sasikala, P.; Rajamani, L.; Kavitha, V.; Yazhini, G. Edible films from polysaccharides. Food Sci. Qual. Manag. 2012, 3, 9-18.

19. Giovanetti, M.H.; Nogueira, A.; de Oliveira, C.L.; Wosiacki, G. Chromatography-The Most Versatile Method of Chemical Analysis; InTech: Rijeka, Croatia, 2012.

20. Sundari, N. Extraction of pectin from waste peels: A review. Res. J. Pharm. Biol. 2015, 6, 1841-1848.

21. Alba, K.; Laws, A.P.; Kontogiorgos, V. Isolation and characterization of acetylated lm-pectins extracted from okra pods. Food Hydrocoll. 2015, 43, 726-735.

22. Maran, J.P. Statistical optimization of aqueous extraction of pectin from waste durian rinds. Int. J. Biol. Macromol. 2015, 73, 92-98. 
23. Geerkens, C.H.; Nagel, A.; Just, K.M.; Miller-Rostek, P.; Kammerer, D.R.; Schweiggert, R.M.; Carle, R. Mango pectin quality as influenced by cultivar, ripeness, peel particle size, blanching, drying, and irradiation. Food Hydrocoll. 2015, 51, 241-251.

24. Oliveira, T.Í.S.; Rosa, M.F.; Cavalcante, F.L.; Pereira, P.H.F.; Moates, G.K.; Wellner, N.; Mazzetto, S.E.; Waldron, K.W.; Azeredo, H.M.C. Optimization of pectin extraction from banana peels with citric acid by using response surface methodology. Food Chem. 2015, in press.

25. Castillo-Israel, K.A.T.; Baguio, S.F.; Diasanta, M.D.B.; Lizardo, R.C.M.; Dizon, E.I.; Mejico, M.I.F. Extraction and characterization of pectin from Saba banana [musa 'saba'(musa acuminata x musa balbisiana)] peel wastes: A preliminary study. Int. Food Res. J. 2015, 22, 202-207.

26. Liew, S.Q.; Chin, N.L.; Yusof, Y.A.; Cheok, C.Y. Citric acid extraction of pectin from tropical fruit peels of passion fruit, dragon fruit and soursop. J. Food Agric. Environ. 2015, 13, 45-51.

27. Li, D.Q.; Du, G.M.; Jing, W.W.; Li, J.F.; Yan, J.Y.; Liu, Z.Y. Combined effects of independent variables on yield and protein content of pectin extracted from sugar beet pulp by citric acid. Carbohyd. Polym. 2015, 129, 108-114.

28. Sánchez Aldana, D.; Contreras-Esquivel, J.C.; Nevárez-Moorillón, G.V.; Aguilar, C.N. Characterization of edible films from pectic extracts and essential oil from mexican lime. CyTA J. Food. 2014, 13, 17-25.

29. Casas-Orozco, D.; Villa, A.L.; Bustamante, F.; González, L.M. Process development and simulation of pectin extraction from orange peels. Food Bioprod. Process. 2015, 96, 86-98.

30. Korish, M. Potential utilization of citrullus lanatus var. Colocynthoides waste as a novel source of pectin. J. Food Sci. Technol. 2015, 52, 2401-2407.

31. Korish, M. Faba bean hulls as a potential source of pectin. J. Food Sci. Technol. 2015, 52, 6061-6066.

32. Denman, L.J.; Morris, G.A. An experimental design approach to the chemical characterisation ofpectin polysaccharides extracted from cucumis melo inodorus. Carbohydr. Polym. 2015, 117, 364-369.

33. Grassino, A.N.; Halambek, J.; Djaković, S.; Rimac Brnčić, S.; Dent, M.; Grabarić, Z. Utilization of tomato peel waste from canning factory as a potential source for pectin production and application as tin corrosion inhibitor. Food Hydrocoll. 2016, 52, 265-274.

34. Kang, J.; Hua, X.; Yang, R.; Chen, Y.; Yang, H. Characterization of natural low-methoxyl pectin from sunflower head extracted by sodium citrate and purified by ultrafiltration. Food Chem. 2015, 180, 98-105.

35. Giosafatto, C.V.L.; di Pierro, P.; Gunning, P.; Mackie, A.; Porta, R.; Mariniello, L. Characterization of citrus pectin edible films containing transglutaminase-modified phaseolin. Carbohydr. Polym. 2014, 106, 200-208.

36. Giosafatto, C.V.L.; Di Pierro, P.; Gunning, A.P.; Mackie, A.; Porta, R.; Mariniello, L. Trehalose-containing hydrocolloid edible films prepared in the presence of transglutaminase. Biopolymers 2014, 101, 931-937.

37. Porta, R.; Mariniello, L.; di Pierro, P.; Sorrentino, A.; Giosafatto, C.V.L. Transglutaminase crosslinked pectin- and chitosan-based edible films: A review. Crit. Rev. Food Sci. Nutr. 2011, 51, 223-238. 
38. Di Pierro, P.; Sorrentino, A.; Mariniello, L.; Giosafatto, C.V.L.; Porta, R. Chitosan/whey protein film as active coating to extend ricotta cheese shelf-life. LWT Food Sci. Technol. 2011, 44, 2324-2327.

39. Rossi Marquez, G.; di Pierro, P.; Esposito, M.; Mariniello, L.; Porta, R. Application of transglutaminase-crosslinked whey protein/pectin films as water barrier coatings in fried and baked foods. Food Bioprocess Technol. 2014, 7, 447-455.

40. Thirugnanasambandham, K.; Sivakumar, V.; Prakash Maran, J. Process optimization and analysis of microwave assisted extraction of pectin from dragon fruit peel. Carbohyd. Polym. 2014, 112, 622-626.

41. Rahmati, S.; Abdullah, A.; Momeny, E.; Kang, O.L. Optimization studies on microwave assisted extraction of dragon fruit (Hylocereus polyrhizus) peel pectin using response surface methodology. Int. Food Res. J. 2015, 22, 233-239.

42. Quoc, L.P.T.; Huyen, V.T.N.; Hue, L.T.N.; Hue, N.T.H.; Thuan, N.H.D.; Tam, N.T.T.; Thuan, N.N.; Duy, T.H. Extraction of pectin from pomelo (Citrus maxima) peels with the assistance of microwave and tartaric acid. Int. Food Res. J. 2015, 22, 1637-1641.

43. Maran, J.P.; Swathi, K.; Jeevitha, P.; Jayalakshmi, J.; Ashvini, G. Microwave-assisted extraction of pectic polysaccharide from waste mango peel. Carbohyd. Polym. 2015, 123, 67-71.

44. Maran, J.P.; Prakash, K.A. Process variables influence on microwave assisted extraction of pectin from waste Carcia papaya L. peel. Int. J. Biol. Macromol. 2015, 73, 202-206.

45. Zouambia, Y.; Youcef Ettoumi, K.; Krea, M.; Moulai-Mostefa, N. A new approach for pectin extraction: Electromagnetic induction heating. Arabian J. Chem. 2014, doi:10.1016/ j.arabjc.2014.11.011.

46. Moorthy, I.G.; Maran, J.P.; Surya, S.M.; Naganyashree, S.; Shivamathi, C.S. Response surface optimization of ultrasound assisted extraction of pectin from pomegranate peel. Int. J. Biol. Macromol. 2015, 72, 1323-1328.

47. Maran, J.P.; Priya, B. Ultrasound-assisted extraction of pectin from sisal waste. Carbohyd. Polym. 2015, 115, 732-738.

48. Chen, H.M.; Fu, X.; Luo, Z.G. Properties and extraction of pectin-enriched materials from sugar beet pulp by ultrasonic-assisted treatment combined with subcritical water. Food Chem. 2015, 168, 302-310.

49. Wang, W.; Ma, X.; Xu, Y.; Cao, Y.; Jiang, Z.; Ding, T.; Ye, X.; Liu, D. Ultrasound-assisted heating extraction of pectin from grapefruit peel: Optimization and comparison with the conventional method. Food Chem. 2015, 178, 106-114.

50. Yuliarti, O.; Matia-Merino, L.; Goh, K.K.T.; Mawson, J.; Williams, M.A.K.; Brennan, C. Characterization of gold kiwifruit pectin from fruit of different maturities and extraction methods. Food Chem. 2015, 166, 479-485.

51. Yuliarti, O.; Goh, K.K.T.; Matia-Merino, L.; Mawson, J.; Brennan, C. Extraction and characterisation of pomace pectin from gold kiwifruit (actinidia chinensis). Food Chem. 2015, 187, 290-296.

52. Valdés, A.; Vidal, L.; Beltrán, A.; Canals, A.; Garrigós, M.C. Microwave-assisted extraction of phenolic compounds from almond skin byproducts (prunus amygdalus): A multivariate analysis approach. J. Agric. Food Chem. 2015, 63, 5395-5402. 
53. Ballard, T.S.; Mallikarjunan, P.; Zhou, K.; O'Keefe, S. Microwave-assisted extraction of phenolic antioxidant compounds from peanut skins. Food Chem. 2010, 120, 1185-1192.

54. Song, J.; Li, D.; Liu, C.; Zhang, Y. Optimized microwave-assisted extraction of total phenolics (TP) from ipomoea batatas leaves and its antioxidant activity. Innov. Food Sci. Emerg. Technol. 2011, 12, 282-287.

55. Montgomery, D.C. Design and Analysis of Experiments; Wiley: Hoboken, NJ, USA, 2009.

56. Falguera, V.; Quintero, J.P.; Jiménez, A.; Muñoz, J.A.; Ibarz, A. Edible films and coatings: Structures, active functions and trends in their use. Trends Food Sci. Technol. 2011, 22, 292-303.

57. Sánchez-Ortega, I.; García-Almendárez, B.E.; Santos-López, E.M.; Amaro-Reyes, A.; Barboza-Corona, J.E.; Regalado, C. Antimicrobial edible films and coatings for meat and meat products preservation. Sci. World J. 2014, doi:10.1155/2014/248935.

58. Rojas-Graü, M.A.; Soliva-Fortuny, R.; Martín-Belloso, O. Edible coatings to incorporate active ingredients to fresh-cut fruits: A review. Trends Food Sci. Technol. 2009, 20, 438-447.

59. Rojas, M.A. Use of edible coatings for fresh-cut fruits and vegetables. In Advances in Fresh-cut Fruits and Vegetables Processing; CRC Press: Boca Raton, FL, USA, 2010; pp. 285-311.

60. Espitia, P.J.P.; Du, W.-X.; Avena-Bustillos, R.d.J.; Soares, N.d.F.F.; McHugh, T.H. Edible films from pectin: Physical-mechanical and antimicrobial properties-A review. Food Hydrocolloid 2014, 35, 287-296.

61. Martín-Diana, A.B.; Rico, D.; Frías, J.M.; Barat, J.M.; Henehan, G.T.M.; Barry-Ryan, C. Calcium for extending the shelf life of fresh whole and minimally processed fruits and vegetables: A review. Trends Food Sci. Technol. 2007, 18, 210-218.

62. Ramirez, M.E.; Timón, M.L.; Petrón, M.J.; Andrés, A.I. Effect of chitosan, pectin and sodium caseinate edible coatings on shelf life of fresh-cut Prunus persica var. Nectarine. J. Food Process. Preserv. 2015, doi:10.1111/jfpp. 12519.

63. Rico, D.; Martín-Diana, A.B.; Barat, J.M.; Barry-Ryan, C. Extending and measuring the quality of fresh-cut fruit and vegetables: A review. Trends Food Sci. Technol. 2007, 18, 373-386.

64. Zhang, Y.; Rempel, C.; McLaren, D. Edible coating and film materials: Carbohydrates. In Innovations in Food Packaging, 2nd ed.; Elsevier: Amsterdam, The Netherlands, 2014; pp. 305-323.

65. Ciolacu, L.; Nicolau, A.I.; Hoorfar, J. Edible coatings for fresh and minimally processed fruits and vegetables. In Global Safety of Fresh Produce; Hoorfar, J., Ed.; Woodhead Publishing: Sawston, UK, 2014; pp. 233-244.

66. Oms-Oliu, G.; Soliva-Fortuny, R.; Martín-Belloso, O. Using polysaccharide-based edible coatings to enhance quality and antioxidant properties of fresh-cut melon. LWT Food Sci. Technol. 2008, 41, 1862-1870.

67. Moalemiyan, M.; Ramaswamy, H.S.; Maftoonazad, N. Pectin-based edible coating for shelf-life extension of ataulfo mango. J. Food Process Eng. 2012, 35, 572-600.

68. Maftoonazad, N.; Ramaswamy, H.S. Effect of pectin-based coating on the kinetics of quality change associated with stored avocados. J. Food Process. Preserv. 2008, 32, 621-643.

69. Ferrari, C.C.; Sarantópoulos, C.I.G.L.; Carmello-Guerreiro, S.M.; Hubinger, M.D. Effect of osmotic dehydration and pectin edible coatings on quality and shelf life of fresh-cut melon. Food Bioprocess Technol. 2013, 6, 80-91. 
70. Sipahi, R.E.; Castell-Perez, M.E.; Moreira, R.G.; Gomes, C.; Castillo, A. Improved multilayered antimicrobial alginate-based edible coating extends the shelf life of fresh-cut watermelon (citrullus lanatus). LWT Food Sci. Technol. 2013, 51, 9-15.

71. Martiñon, M.E.; Moreira, R.G.; Castell-Perez, M.E.; Gomes, C. Development of a multilayered antimicrobial edible coating for shelf-life extension of fresh-cut cantaloupe (Cucumis melo L.) stored at $4{ }^{\circ} \mathrm{C}$. LWT-Food Sci. Technol. 2014, 56, 341-350.

72. Brasil, I.M.; Gomes, C.; Puerta-Gomez, A.; Castell-Perez, M.E.; Moreira, R.G. Polysaccharide-based multilayered antimicrobial edible coating enhances quality of fresh-cut papaya. LWT-Food Sci. Technol. 2012, 47, 39-45.

73. Oms-Oliu, G.; Soliva-Fortuny, R.; Martín-Belloso, O. Edible coatings with antibrowning agents to maintain sensory quality and antioxidant properties of fresh-cut pears. Postharvest Biol. Technol. 2008, 50, 87-94.

74. Treviño-Garza, M.Z.; García, S.; Flores-González, M.S.; Arévalo-Niño, K. Edible active coatings based on pectin, pullulan, and chitosan increase quality and shelf life of strawberries (Fragaria ananassa). J. Food Sci. 2015, 80, M1823-M1830.

75. Moreira, M.R.; Cassani, L.; Martín-Belloso, O.; Soliva-Fortuny, R. Effects of polysaccharide-based edible coatings enriched with dietary fiber on quality attributes of fresh-cut apples. J. Food Sci. Technol. 2015, doi:10.1007/s13197-015-1907-z.

76. Guerreiro, A.C.; Gago, C.M.L.; Faleiro, M.L.; Miguel, M.G.C.; Antunes, M.D.C. The use of polysaccharide-based edible coatings enriched with essential oils to improve shelf-life of strawberries. Postharvest Biol. Technol. 2015, 110, 51-60.

77. Guerreiro, A.C.; Gago, C.M.L.; Faleiro, M.L.; Miguel, M.G.C.; Antunes, M.D.C. Raspberry fresh fruit quality as affected by pectin- and alginate-based edible coatings enriched with essential oils. Sci. Hortic. 2015, 194, 138-146.

78. Ayala-Zavala, J.F.; Silva-Espinoza, B.A.; Cruz-Valenzuela, M.R.; Leyva, J.M.; Ortega-Ramírez, L.A.; Carrazco-Lugo, D.K.; Pérez-Carlón, J.J.; Melgarejo-Flores, B.G.; González-Aguilar, G.A.; Miranda, M.R.A. Pectin-cinnamon leaf oil coatings add antioxidant and antibacterial properties to fresh-cut peach. Flavour Fragr. J. 2013, 28, 39-45.

79. Valdes, A.; Mellinas, A.C.; Ramos, M.; Burgos, N.; Jimenez, A.; Garrigos, M.C. Use of herbs, spices and their bioactive compounds in active food packaging. RSC Adv. 2015, 5, 40324-40335.

80. Mellinas, C.; Valdés, A.; Ramos, M.; Burgos, N.; del Carmen Garrigós, M.; Jiménez, A. Active edible films: Current state and future trends. J. Appl. Polym. Sci. 2015, doi:10.1002/app.42631.

81. Daraei Garmakhany, A.; Mirzaei, H.O.; Maghsudlo, Y.; Kashaninejad, M.; Jafari, S.M. Production of low fat french-fries with single and multi-layer hydrocolloid coatings. J. Food Sci. Technol. 2014, $51,1334-1341$.

82. Suyatma, N.E.; Ulfah, K.; Prangdimurti, E.; Ishikawa, Y. Effect of blanching and pectin coating as pre-frying treatments to reduce acrylamide formation in banana chips. Int. Food Res. J. 2015, 22, 936-942.

83. Oliveira, S.M.; Brandão, T.R.S.; Silva, C.L.M. Influence of drying processes and pretreatments on nutritional and bioactive characteristics of dried vegetables: A review. Food Eng. Rev. 2015, doi:10.1007/s12393-015-9124-0. 
84. Garcia, C.C.; Caetano, L.C.; de Souza Silva, K.; Mauro, M.A. Influence of edible coating on the drying and quality of papaya (Carica papaya). Food Bioprocess Technol. 2014, 7, 2828-2839.

85. Silva, K.S.; Garcia, C.C.; Amado, L.R.; Mauro, M.A. Effects of edible coatings on convective drying and characteristics of the dried pineapple. Food Bioprocess Technol. 2015, 8, 1465-1475.

86. Canizares, D.; Mauro, M.A. Enhancement of quality and stability of dried papaya by pectin-based coatings as air-drying pretreatment. Food Bioprocess Technol. 2015, 8, 1187-1197.

87. Akbarian, M.; Ghanbarzadeh, B.; Sowti, M.; Dehghannya, J. Effects of pectin-CMC-based coating and osmotic dehydration pretreatments on microstructure and texture of the hot-air dried quince slices. J. Food Process. Preserv. 2015, 39, 260-269.

(C) 2015 by the authors; licensee MDPI, Basel, Switzerland. This article is an open access article distributed under the terms and conditions of the Creative Commons Attribution license (http://creativecommons.org/licenses/by/4.0/). 